\title{
TOXICOLOGICAL AND BIOLOGICAL EFFECTS OF BACTERIA, Bacillus thuringiensis KURSTAKI ON Pectinophora gossypiella (SAUND.), AND ENTOMOPATHOGENIC FUNGI, Beauveria bassiana ON Earias insulana (BOISD.)
}

Hegab, M. E. M. A. and A. A. A. Zaki

Plant Protection Res., Inst., Agric. Res. Center, Dokki, Giza, Egypt

\begin{abstract}
Laboratory studies were conducted for evaluate the effect of Dipel $2 x$, (Bacillus thuringiensis Kurstaki) against pink bollworm Pectinophora gossypiella (Saund.), and Biover ${ }^{\circledR}$ (Beauveria bassiana) (Balsamo) against spiny bollworm, Earias insulana (Boisd.). The accumulated mortalities of both pink bollworm, Pectinophora gossypiella and spiny bollworm, Earias insulana larvae, after six days of treatment, were represented as the acute toxicity were, Dipel $2 \times$ attained $17.18 \pm 0.63$ $\%$ larval mortality at $32 \times 10^{6} \mathrm{IU}$ concentration against $P$. gossypiella larvae while Biover® resulted in $15.55 \pm 0.59 \%$ larval mortality against Earias insulana larvae comparing with $0.00 \%$ larval mortality in untreated check.

At the same time the tested biocide Btk (Dipel $2 \times$ ) caused different influences on all biological aspects of pink bollworm which decreasing larval duration, pupal weight, pupation percentage, adult emergence, oviposition periods, adult longevity, female fecundity decreased strongly which recorded $149.75 \pm 5.23$ egg/female comparing with that $362.00 \pm 2.31 \mathrm{egg} / \mathrm{female}$ in untreated check. The tested biocide Btk (Dipel $2 \times$ ) also decreasing hatchability percentage that exhibited $73.16 \pm 1.15 \%$ as compared with $88.09 \pm 0.57 \%$ that achieved in untreated check. Also, results cleared that the effect of Biover ${ }^{\circledR}$ fungi attained decreasing in all biological aspects, except the male and female longevity and oviposition periods compared with untreated check. Female fecundity was moderately influenced when spiny bollworm larvae treated by Biover ${ }^{\circledR}$ that achieved $60.33 \pm 11.66$ eggs compared with $78.33 \pm 5.78$ eggs laid /female deposited by check females. Hatchability percentage of spiny bollworm also decreased vigorously which attained $41.12 \pm 6.45 \%$ as compared with that $82.33 \pm 7.51 \%$ in untreated once.
\end{abstract}

Keywords: Bacillus thuringiensis Kurstaki, Dipel 2×, Pectinophora gossypiella Beauveria bassiana, Biover®, Earias insulana, concentration, biocides.

\section{INTRODUCTION}

In Egypt, during the late cotton-season, cotton plants suffer from the infestation with pink bollworm, Pectinophora gossypiella and the spiny bollworm, Earias insulana. Both bollworms are of the most serious insects that constitute a major part of the pest complex on cotton in Egypt. The loss caused by $P$. gossypiella to cotton arises to one million kentar annually. Although new insecticides give excellent control to resistant strains of insects, no one can accurately predict how long resistant insect populations will take 
to develop (Metwally et al, 1980). In Egypt studied the effect of Dipel 2x, (Bt kurstaki) and Xantari, (Bt aizawia) against pink bollworm larvae to determine the LC 50 by feeding neonate larvae on artificial diet. Results revealed that Dipel 2x (powder) and Xentari were more effective against pink bollworm than their mixture (s),i.e. Bt. sub sp. kurstaki and Bt aizawia were note compatible (Karima, El-Lebody 2003). (Bt kurstakı) and Xantari caused significant inhibition of growth of pink bollworm (Ibargutxi et al. 2006). Entomopathogenic fungi in common with other insect natural enemies can be employed for biocontrol strategies (Shah and Pell 2003). Laboratory studies reported that Dpiel $2 x$ compound was the most toxic biocide against pink and spiny bollworms neonate larvae (Hegab, 2008).

Therefore, the present study aims to throw some light on the toxic and latent effect of Dipel 2x, (Bacillus thuringiensis kurstaki) and entomopathogenic fungi Biover ${ }^{\circledR}$, (Beauveria bassiana) against pink and spiny bollworms, under laboratory conditions.

\section{MATERIALS AND METHODS}

Acute and chronic Effects, of some biocides, on the pink and spiny
bollworms.
Mass Rearing:
$\quad$ Newly hatched larvae of Pink bollworm, Pectinophora gossypiella (Sunders) susceptible strain (PBW) which reared in culture in bollworm research Department, Plant Protection Research Institute, (Sharkia branch) have been described by (Abd El-Hafez et al. 1982). In case of SBW, fullgrown larvae were collected from infested green cotton bolls obtained from the field at the end of cotton growing seasons and a mass rearing was prepared in incubator at $26 \pm 1^{\circ} \mathrm{C}$ and $80 \pm 5 \%$ R.H. at Plant Protection Research Institute, Sharkia branch Lab. then reared on artificial diet described previously by Amira, M. Rashad and Ammar (1985).

Tested compounds:

A. Dipel 2X, a commercial formulation of Bacillus thuringiensis kurstaki

(Berliner) (Btk) it is a product of the Special Unit for producing bioinsecticides, plant protection research institute Agriculture research center, Egypt,with $32 \times 10^{6}$ international toxicity units, based on rate of application per feddan of $200 \mathrm{~g} . / 400$ Liter water.

B. Biover ${ }^{\circledR}$, a commercial formulation of Beauveria bassiana (Balsamo) it is a product of the same unit with $32 \times 10^{6}$ viable spores per $\mathrm{mg}$. based on rate of application per feddan of $200 \mathrm{~g}$. $/ 400$ Liter water.

\section{Test trials:}

Five grams of kidney been artificial diet were putted in each Petri dish $(7 \mathrm{~cm}$ diameter $\times 1.5 \mathrm{~cm}$ in height). The concentration tested $(0.5 \mathrm{~g}$. of each biocides were diluted in one liter water). One $\mathrm{ml}$ of the tested concentrations of both Dipel 2X and Biover® were distributed on the surface of the diet then were left to dry. Twenty newly hatched larvae of PBW or SBW were transferred to the surface of treated media in Petri dishes after drying. Petri dishes were covered by fine and soft paper below the glass cover and placed in an electrical incubator running at $26 \pm 1^{\circ} \mathrm{C}$ and $80 \pm 5 \%$ R.H. Three 
replicates for every treatment were done. After $24 \mathrm{hr}$ of exposure and feeding, alive larvae of both pink and spiny bollworms were transferred individually to glass tube, $(2 \times 7.5 \mathrm{~cm})$, containing about four grams of untreated media and the glass tubes were covered with a piece of absorbent cotton and held in incubator under the above mentioned conditions. The treated larvae were inspected daily and the dead larvae were recorded till pupation. Percent of larval mortalities were deduced after 6 days (which considered as a toxic effect) of Dipel $2 X$ and Biover ${ }^{\circledR}$ tested biocides. To record the biological aspects i.e. larval duration, weight of $4^{\text {th }}$ instar larvae, pupal duration and pupation percentage. Emerged moths were coupled (for five replicates for every treatment). Moths of two tested pests were caged in a glass Jar $(250 \mathrm{ml}$ in size) covered with muslin clothes, and secured by rubber bands. Moths were fed on $10 \%$ sucrose solution, using soaked cotton wool and changed by new one daily. Paper piece was putted over the upper opining of the Jar serving as oviposition site. Each Jar was inspected daily to record the number of deposited eggs/ female till death. Fecundity, oviposition periods as female, male and female longevities, and hatchability percentages were calculated and recorded.

\section{Statistical analysis:}

The obtained results of each mortality and biological parameters were subjected to analysis of variance to clear Standard Error values of insect's toxicity and latent effect parameters. The analysis of variance was computed using Costat computer program Cohort Software. P. O. Box 1149, Berkeley CA 9471 (Costat program methods 1990).

\section{RESULTS AND DISCUSSION}

\section{Acute and chronic Effects, of some biocides on the pink and spiny bollworms. \\ Acute effect:}

The accumulated mortalities of both Pectinophora gossypiella and Earias insulana larvae, after six days of treatment, were represented as the acute toxicity.

Data in Table (1) indicated that Dipel $2 X$ recorded mortality percentage of $(17.18 \pm 0.63 \%)$ on Pectinophora gossypiella, While Biover ${ }^{\circledR}$ recorded (15.55 $\pm 0.59 \%)$ against spiny bollworm larvae after 6 days from treatment as compared with control treatment that recorded $(0.00 \%)$.

These results coincide the moderately effect of both Ecotch, Btk and Dipel $2 x$ at different concentrations against Spodoptera littoralis newly hatched larvae and a low degree of efficiency inhibiting $10.50 \%$ mortality (AlShannaf, 2002). Bacillus thuringiensis Kurstaki strain exhibiting high toxicity against $S$. exigua while retaining its high toxicity against Helicoverpa armigera. The toxicity of Btk, D1-23 against $S$. exigua and Helicoverpa armigera was improved by 15.4 and $25.9 \%$, respectively (Zhang et al. 2009). The effects of Beauveria bassiana $\mathrm{Bb} 21$ strain had strong pathogenicity on Myzus persicae, at laboratory condition with the $\mathrm{LD}_{50}$ of 97 conidia $\times \mathrm{mm}(-2)$ (45-191, 95\% confidence interval), but was less pathogenic to the second instar nymph of Chrysoperla carnea, with the LD $_{50}$ of 1089 conidia $\times$ mm (-2). 
The pathogenicity of $\mathrm{Bb} 21$ to Harmonia axyridis was very weak, with a low infection rate of $13 \%$ even at a high concentration $5 \times 10(8)$ conidia $\times \mathrm{mL}(-1)$. When applied at the high concentration $5 \times 10(8)$ spores $\times \mathrm{mL}(-1), \mathrm{Bb} 21$ shortened the larval stage of $H$. axyridis averagely by $1.4 \mathrm{~d}$ and decreased the adult emergence rate and fecundity by $33 \%$ and $14 \%$, respectively (Zhu et al. 2011).

Latent effect:

A Latent effect of Dipel $2 x$ and Biover ${ }^{\circledR}$ tested biocides on pink and spiny bollworms larvae was expressed as some biological aspects including, larval duration, weight of $4^{\text {th }}$ instars larvae, pupation percentage, pupal weight, pupal duration, percent of adult emergence, oviposition periods of emerged females, longevity of males and females, female fecundity and hatchability percentage.

\section{larval duration:}

Data summarized in Table (1) revealed that Dipel 2x, Btk caused shortening in larval duration up to $12.62 \pm 0.59$ days compared with untreated larvae which recorded $\left(14.89 \pm 0.041\right.$ days). While Biover ${ }^{\circledR} B$. bassiana entomopathogenic fungi caused highly decreased in larval duration (10.42 \pm 0.29 days) compared with $(16.13 \pm 0.16$ days) which recorded in untreated larvae.

Weight of the $4^{\text {th }}$ instar larvae:

Data presented in Table (1) showed that, the influence of Dipel $2 x$, $B$ tk tested concentration caused slight decreased in larval weight where attained $\left(0.0483 \pm 0.0058 \mathrm{~g}\right.$.) at $32 \times 10^{6}$ Unit concentration, comparing with $(0.0488 \pm 0.006 \mathrm{~g}$.) which recorded in untreated check. Meanwhile in case of spiny bollworm treated larvae by Biover $\AA, B$. bassiana the larval weight was $(0.0783 \pm 0.0014 \mathrm{~g}$.) as compared with $(0.0786 \pm 0.0015 \mathrm{~g}$.) in untreated check.

Table (1): Effect of the tested biocides on larval, pupal and adult emergence of pink and spiny bollworms under laboratory conditions

\begin{tabular}{|c|c|c|c|c|c|c|c|c|c|c|}
\hline 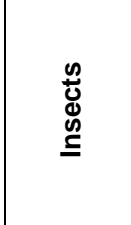 & 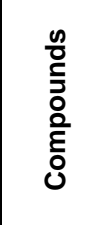 & 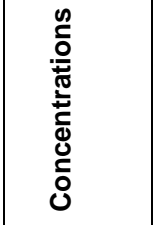 & 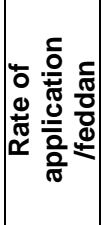 & 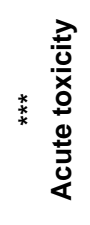 & 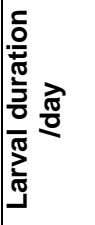 & 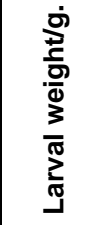 & $\begin{array}{l}\frac{9}{2} \\
\frac{0}{0} \\
\frac{0}{01} \\
\frac{3}{\pi} \\
\frac{0}{3} \\
0\end{array}$ & 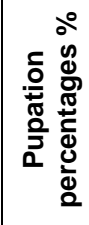 & 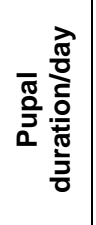 & 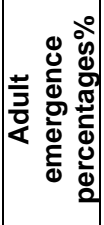 \\
\hline $\begin{array}{c}\text { Pink } \\
\text { bollworm }\end{array}$ & $\begin{array}{l}\text { * Dipel } \\
2 x\end{array}$ & $32 \times 10^{6}$ Unit & $200 \mathrm{~g}$ & $\begin{array}{c}17.18 \\
\pm \\
0.63 \\
\end{array}$ & \begin{tabular}{|c|}
12.62 \\
\pm \\
0.59 \\
\end{tabular} & \begin{tabular}{|c|}
0.0483 \\
\pm \\
0.0058 \\
\end{tabular} & \begin{tabular}{|c|}
0.0384 \\
\pm \\
0.0006 \\
\end{tabular} & $\begin{array}{c}77.21 \\
\pm \\
4.05 \\
\end{array}$ & \begin{tabular}{c|}
25.50 \\
\pm \\
0.64 \\
\end{tabular} & \begin{tabular}{|c|}
77.21 \\
\pm \\
4.05 \\
\end{tabular} \\
\hline \multicolumn{4}{|c|}{ Control } & 0.00 & \begin{tabular}{|c|}
14.89 \\
\pm \\
0.041 \\
\end{tabular} & $\begin{array}{c}0.0488 \\
\pm \\
0.006 \\
\end{array}$ & $\begin{array}{c}0.0398 \\
\pm \\
0.0004 \\
\end{array}$ & \begin{tabular}{|c|}
85.55 \\
\pm \\
2.92 \\
\end{tabular} & $\begin{array}{c}10.69 \\
\pm \\
0.56 \\
\end{array}$ & \begin{tabular}{|c|}
85.55 \\
\pm \\
2.92 \\
\end{tabular} \\
\hline $\begin{array}{c}\text { Spiny } \\
\text { bollworm }\end{array}$ & 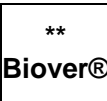 & $\begin{array}{c}32 \times 10^{6} \text { Unit } \\
\text { viable } \\
\text { spores } / \mathrm{mg}\end{array}$ & $200 \mathrm{~g}$. & $\begin{array}{c}15.55 \\
\pm \\
0.59\end{array}$ & $\begin{array}{c}10.42 \\
\pm \\
0.29\end{array}$ & $\begin{array}{c}0.0783 \\
\pm \\
0.0014\end{array}$ & $\begin{array}{c}0.0533 \\
\pm \\
0.0004\end{array}$ & $\begin{array}{c}35.00 \\
\pm \\
4.81\end{array}$ & $\begin{array}{c}8.93 \\
\pm \\
0.043\end{array}$ & \begin{tabular}{|c|}
83.34 \\
\pm \\
1.93 \\
\end{tabular} \\
\hline \multicolumn{4}{|c|}{ Control } & 0.00 & $\begin{array}{c}16.13 \\
\pm \\
0.16\end{array}$ & $\begin{array}{c}0.0786 \\
\pm \\
0.0015\end{array}$ & $\begin{array}{c}0.0684 \\
\pm \\
0.0005\end{array}$ & $\begin{array}{c}96.43 \\
\pm \\
1.73\end{array}$ & $\begin{array}{c}10.89 \\
\pm \\
0.14\end{array}$ & \begin{tabular}{|c|}
85.85 \\
\pm \\
0.084
\end{tabular} \\
\hline
\end{tabular}


Generally the two tested bio-compounds revealed slight decrease in the weight of the $4^{\text {th }}$ instar larvae of the two tested insects.

\section{Pupal weight:}

Data in Table (1) indicated Dipel 2x, Btk decreased pupal weight which achieved $(0.0384 \pm 0.0006$ g.) comparing with $(0.0398 \pm 0.0004 \mathrm{~g}$.) obtained in untreated once. Results also, proved that entomopathogenic fungi Biover ${ }^{\circledR}$ exhibited $(0.0533 \pm 0.0004 \mathrm{~g}$.) as compared with $(0.0684 \pm 0.0005)$ which attained with untreated check.

\section{Pupation Percentages:}

The data in Table (1) indicated that, the tested concentration of Dipel $2 \mathrm{x}$, Btk reduced the pupation percentage by $77.21 \pm 4.05 \%$ compared with $(85.55 \pm 2.92 \%)$ which was recorded with check experiment. Also results in the same Table showed that Biover ${ }^{\circledR}, B$. bassiana caused strongly decreased pupation percentage that attained $(35.00 \pm 4.81 \%)$ as comparing with that of $(96.43 \pm 1.73 \%)$ which recorded in untreated check.

\section{Pupal duration:}

Also present results proved that Dipel 2x, Btk tested compound caused highly prolongation in pupal duration showing $25.50 \pm 0.64$ days compared with $10.69 \pm 0.56$ days which attained in control. Also, results in the same Table proved that the influence of Biover ${ }^{\circledR}$ fungi tested against spiny bollworm caused mediate decrease in pupal duration which achieved $8.93 \pm 0.043$ days compared with that of $10.89 \pm 0.14$ days that exhibited in untreated larvae.

\section{Adult emergence percentages:}

Also present results indicated that Dipel 2x, Btk tested biocide was resulted in emergence percentage of $77.21 \pm 4.05 \%$ compared with $85.55 \pm 2.92 \%$ for control. Also results tabulated in the same Table showed that the entomopathogenic fungi Biover ${ }^{\circledR}$ tested biocide attained $(83.34 \pm 1.93 \%)$ compared with that of $85.85 \pm 0.084 \%$ in untreated check.

\section{Oviposition periods of emerged females:}

Pre-oviposition period:

Also data showed that Dipel $2 \mathrm{x}$, Btk had slightly effect the tested parameter and attained ( $2.00 \pm 0.58$ days), compared with $(2.25 \pm 0.59$ days) for untreated check. Meanwhile the other tested biocide Biover ${ }^{\circledR}$ caused prolongation in pre oviposition period of spiny bollworm which attained (4.33 \pm 0.66 days) compared with ( $2.17 \pm 0.69$ days) for untreated once.

\section{Oviposition period:}

As shown in Table (2) the effect of Dipel 2x, Btk on pink bollworm female moths, which caused prolongation in oviposition periods that recorded (21.50 \pm 0.69 days), comparing with that $(15.25 \pm 0.56$ days) of untreated check. Also, results tabulated in the same Table showed that the entomopathogenic fungi Biover ${ }^{\circledR}$ tested against spiny bollworm resulted in prolongation this period up to $9.33 \pm 1.33$ days as compared with $8.00 \pm 0.58$ day that recorded in untreated once.

\section{Post-oviposition period:}

Also data presented revealed that, the post-oviposition period for pink bollworm female were $(1.50 \pm 0.69$ days) when treated by Dipel $2 x$, Btk comparing with untreated check that exhibit $1.38 \pm 0.57$ days. But the influence 
of Biover ${ }^{\circledR}$ tested biocide against spiny bollworm was $7.00 \pm 1.53$ days compared with that $(4.66 \pm 0.88$ days $)$ recorded in untreated check as a postoviposition period.

Table (2): Effect of Bacillus thuringiensis Kurstaki and Beauveria bassiana on immature stages of the pink and spiny bollworms.

\begin{tabular}{|c|c|c|c|c|c|c|c|c|c|c|}
\hline \multirow{2}{*}{ 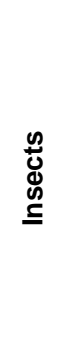 } & \multirow{2}{*}{$\begin{array}{l}\text { on } \\
\text { c } \\
\text { o } \\
\text { 을 } \\
\text { o }\end{array}$} & \multirow{2}{*}{ 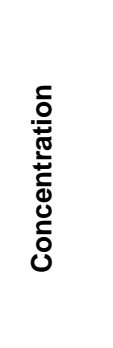 } & \multirow{2}{*}{ 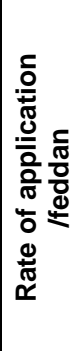 } & \multicolumn{3}{|c|}{ Oviposition period/female/day } & \multicolumn{2}{|c|}{$\begin{array}{c}\text { Adult } \\
\text { longevity in } \\
\text { days }\end{array}$} & \multirow{2}{*}{ 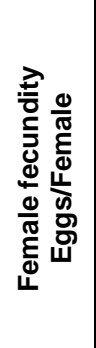 } & \multirow{2}{*}{ 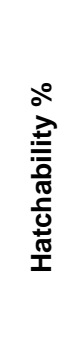 } \\
\hline & & & & d & 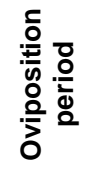 & 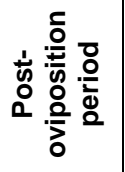 & 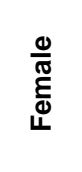 & $\frac{\Phi}{\frac{0}{\pi}}$ & & \\
\hline 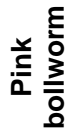 & $\begin{array}{c}\text { * Dipel } \\
2 x\end{array}$ & $\begin{array}{c}32 \times 10^{6} \\
\text { IU }\end{array}$ & $200 \mathrm{~g}$ & $\begin{array}{c}2.00 \\
\pm \\
0.58\end{array}$ & $\begin{array}{c}21.50 \\
\pm \\
0.69\end{array}$ & $\begin{array}{c}1.50 \\
\pm \\
0.69\end{array}$ & $\begin{array}{c}25.00 \\
1 \pm \\
1.20\end{array}$ & $\begin{array}{c}22.63 \\
\pm \\
0.59\end{array}$ & $\begin{array}{c}149.75 \\
\pm \\
5.23\end{array}$ & $\begin{array}{c}73.16 \\
\pm \\
1.15\end{array}$ \\
\hline \multicolumn{4}{|c|}{ Control } & $\begin{array}{c}2.25 \\
\pm \\
0.59 \\
\end{array}$ & $\begin{array}{c}15.25 \\
\pm \\
0.56 \\
\end{array}$ & $\begin{array}{c}1.38 \\
\pm \\
0.57\end{array}$ & $\begin{array}{c}18.88 \\
\pm \\
0.60 \\
\end{array}$ & $\begin{array}{c}23.88 \\
\pm \\
0.57 \\
\end{array}$ & $\begin{array}{c}362.00 \\
\pm \\
2.31 \\
\end{array}$ & $\begin{array}{c}88.09 \\
\pm \\
0.57 \\
\end{array}$ \\
\hline 층 & 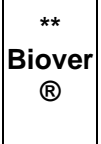 & $\begin{array}{c}32 \times 10^{6} \\
\text { viable } \\
\text { spores/ } \\
\text { mg }\end{array}$ & $200 \mathrm{~g}$ & $\begin{array}{c}4.33 \\
\pm \\
0.66\end{array}$ & $\begin{array}{c}9.33 \\
\pm \\
1.33\end{array}$ & $\begin{array}{c}7.0 \\
\pm \\
1.53\end{array}$ & $\begin{array}{c}20.67 \\
\pm \\
3.18\end{array}$ & $\begin{array}{c}20.00 \\
\pm \\
1.53\end{array}$ & $\begin{array}{c}60.33 \\
\pm \\
11.66\end{array}$ & $\begin{array}{c}41.12 \\
\pm \\
6.45\end{array}$ \\
\hline \multicolumn{4}{|c|}{ Control } & $\begin{array}{c}2.17 \\
\pm \\
0.69\end{array}$ & $\begin{array}{c}8.00 \\
\pm \\
0.58\end{array}$ & $\begin{array}{c}4.66 \\
\pm \\
0.88\end{array}$ & $\begin{array}{c}14.83 \\
\pm \\
0.35\end{array}$ & $\begin{array}{c}15.67 \\
\pm \\
0.88\end{array}$ & $\begin{array}{c}78.33 \\
\pm \\
5.78\end{array}$ & $\begin{array}{c}82.33 \\
\pm \\
7.51\end{array}$ \\
\hline
\end{tabular}

** Biover $\AA$, Beauveria bassiana $\pm=$ Standard Error

\section{Adult longevity:}

\section{A- Female:}

Also data showed that Dipel 2x, Btk achieved prolongation in female longevity $(25.00 \pm 1.20$ days), as compared with (18.88 \pm 0.60 days) that recorded with untreated one. On the other hand, Biover ${ }^{\circledR}$ tested biocide against spiny bollworm also, attained prolongation in female longevity $20.67 \pm 3.18$ days as compared with $14.83 \pm 0.35$ in untreated check.

\section{B-Male:}

Also data indicated that, the Dipel 2x, Btk tested biocide lead to slight shortening in male longevity $(22.63 \pm 0.59$ days) comparing with $23.88 \pm 0.57$ days in untreated check. While the effect of Biover ${ }^{\circledR}$ entomopathogenic fungi tested against spiny bollworm achieved $20.00 \pm 1.53$ days compared with $15.67 \pm 0.88$ days which exhibited in untreated check. 
Female fecundity:

Also present results indicated that the tested bacteria, Btk achieved a highly noticeable reduction in the female fecundity which recorded $(149.75 \pm 5.23 \%)$ comparing with $(362.00 \pm 2.31 \%)$ that attained in untreated check. Also, results proved that Biover ${ }^{\circledR}$ tested fungi attained highly decreasing in female fecundity $60.33 \pm 11.66$ eggs laid/female as comparing with that $78.33 \pm 5.78$ eggs laid/female in untreated once.

The present results agree with those obtained by (Moawad et al. 1996) who found that increasing the used concentration of biocide Bt caused an elongation of female longevity of Spodoptera littoralis. Increasing the used concentrations of Ecotch, Dipel $2 x$ and Bioclean caused a shortness adult longevity (Al-Shannaf, 2002). Similar results were obtained by (Salama and Zaki 1986) and (Moawad et al. 1996). Interactive effect of Bacillus thuringiensis var. Kurstaki HD-1 and proteinase inhibitors in the larvae of Helicoverpa armigera depended upon the quality and quantity of proteinase inhibitors, which vary widely in different plants (Gujar et al. 2004).

Hatchability of eggs:

The tested bacteria Dipel $2 x$ decreased hatchability percentage of pink bollworm where recorded $73.16 \pm 1.15 \%$ comparing with $88.09 \pm 0.57 \%$ in untreated check. Meanwhile the tested Biover ${ }^{\circledR}$ caused highly decreasing in spiny bollworm hatchability percentage which attained $41.12 \pm 6.45 \%$ as compared with $82.33 \pm 7.51 \%$ achieved in untreated check.

The obtained results are in agree with (Al-Shannaf, 2002) who found that the influence of Dipel 2x, Ecotch and Bioclean biocides on the fecundity of emerged females decreased significantly. The average number of eggmass deposited by emerged female was decreased with increasing the used concentration of each biocide. The percent of hatching eggs of pink bollworm was significantly reduced by Chinimix and Spintor the influence of Biorepel had insignificant effect. Increasing the concentration of all tested compounds induced a gradual decreased in hatchability of eggs (Amer, 2004). Fungal endophytes negative effects on the fitness of $H$. armigera first generation. The reduction in fitness parameters of $H$. armigera across two generations is caused indirectly via an endophyte-triggered reduction in plant quality (Lara and Stefan 2009). Laboratory experiments on the evaluation of infectivity of Beauveria bassiana (Bals.) Vuill. to tobacco caterpillar Spodoptera litura as influenced by two okra varieties(Suganya and Selvanarayanan 2010).

\section{REFERENCES}

Abd El-Hafez, A.; A. G. Metwaly and M.R.A. Saleh (1982): Rearing pink bollworm, Pectinophora gossypiella (Saunders) on kidney bean diet in Egypt (Lepidoptera: Gelechiidae). Res. Bull. Fac. of Agric., Zagazig Univ., No. 576, 10 pp.

Amira, M. Rashad; and E. D. Ammar (1985): Mass rearing of the spiny bollworm, Earias insulana (Boisd.) on semi-artificial diet. Bull. Entomol. Soc. Egypt, 65:239-244. 
Al-Shannaf, M. H. A. (2002): Studies on some cotton pests. Ph.D. Thesis. Fac. Agric. Zagazig Univ., 297 pp.

Amer, A. E. A. (2004): Ecological and physiological Studies on bollworms.Ph.D. Thesis, Fac., Moshtohor Branch, Zagazig Univ., Egypt. 213 pp.

Costat, Software (1990): Micro Computer Program Analysis version 4-20, CoHort Software, Berkly, CA.

Gujar, T.; V. Kalia; A. Kumari and T.V. Prasad ( 2004): Potentiation of insecticidal activity of Bacillus thuringiensis subsp. kurstaki HD-1 by proteinase inhibitors in the American bollworm, Helicoverpa armigera (Hübner). Indian J. Exp. Biol. Feb.;42 (2):157-63.

Hegab, M. E. M. (2008): Studies on some elements of integrated control of cotton bollworms. Ph.D.Thesis, Fac. Agric. Al-Azhar University, $231 \mathrm{pp}$.

Ibargutxi, M. A.; A. Estela; J. Ferre and P. Caballero (2006): Use of Bacillus thuringiensis toxins for control of the cotton pest Earias insulana (Boisd.) (Lepidoptera: Noctuidae). Appl. Environ. Microbiol.; 72 (1):437-442.

Karima, A. El-Lebody (2003): An idea for table invitation to determine the kind and rate of the used insecticide and the proper time of spray against cotton bollworm infestation with pink bollworm Pectinophora gossypiella. The first Int. Egyptian, Romanian Conf. , Zagazig , Egypt, Dec., 6-8 $8^{\text {th }}$.

Lara, R. J. and V. Stefan (2009): Fungal endophyte negative effects on herbivory are enhanced on intact plants and maintained in a subsequent generation. Ecological Entomology, 35, 25-36.

Metwally, A. G.; A. Abdel-Hafez; A. Khalifa and M. F. El-Shaarawy (1980): Breeding pink bollworm on different host plants. $1^{\text {st }}$ Conf., PI. Prot. Res. Ins., Cairo, Egypt.

Moawad, G. M.; Z. H. Zidan and E. E. Fatma El-Swerki (1996): Latent bioinsecticidal effects of certain soft nontoxic compounds on the cotton leafworm, Spodoptera littoralis (Boisd.) treated as eggs. Annals Agric.,Sci.,Sp.Issue:255-264.

Salama, H. S. and F. N. Zaki (1986): Effect of Bacillus thuringiensis Berliner on pre-pupal and pupal stages of Spodoptera littoralis (Boisd.) (Lepidoptera: Noctuidae).Insect Science and its Application, 7(6):747749.

Shah, P. A. and J. K. Pell (2003): Entomopathogenic fungi as biological control agents. Appl. Microbiol. Biotechnol., 61, 413-423.

Suganya,T. and V. Selvanarayanan (2010): In vitro study on the effect of bhendi varieties on the infectivity of Beauveria bassiana (Bals.)Vuill to Spodoptera litura Fab. Journal of Biopesticides 3(1 Special Issue) 369 372 .

Zhang, X., Z. Liang; Z. A. Siddiqui; Y. Gong; Z. Yu and S. Chen (2009): Efficient screening and breeding of Bacillus thuringiensis subsp. kurstaki for high toxicity against Spodoptera exigua and Heliothis armigera. J. Ind. Microbiol. Biotechnol. 815-820. 
Zhu, H.; X. M. Luo ; J. X. Song ; M. Z. Fan and Z. Z. Li (2011): [Effects of Beauveria bassiana on Myzus persicae and its two predaceous natural enemies].Ying Yong Sheng Tai Xue Bao. ; 22(9):2413-2418.

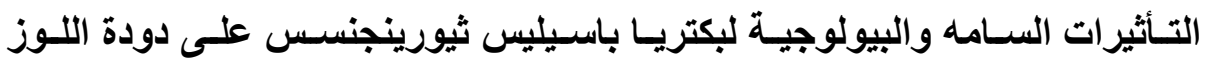

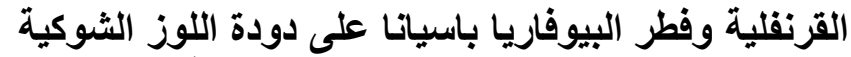

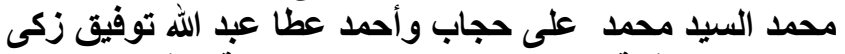
معهد بحوث وقاية النباتات-مركز البحوث الزراعية_الدقى_الجيزة -مصر توكر

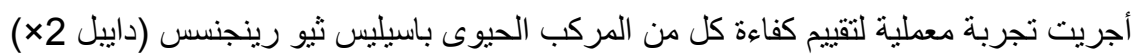

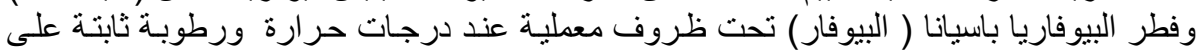

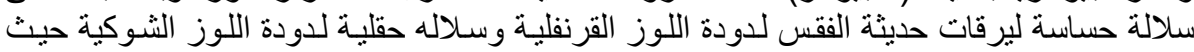

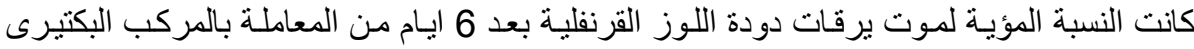

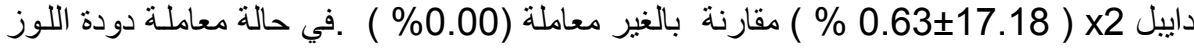

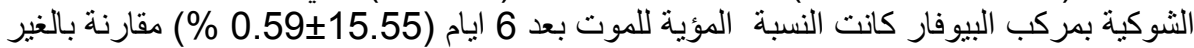

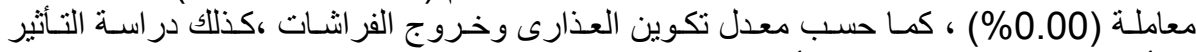

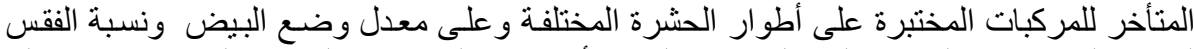

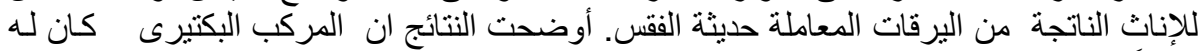

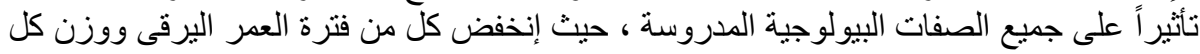

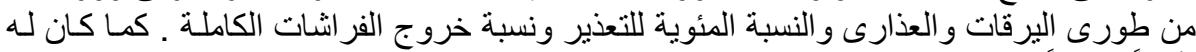

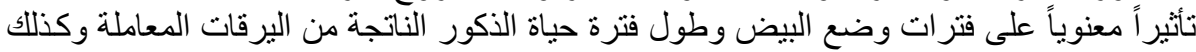

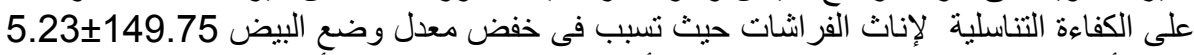

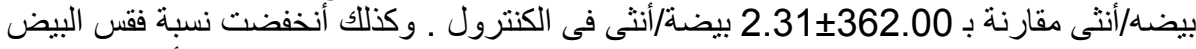

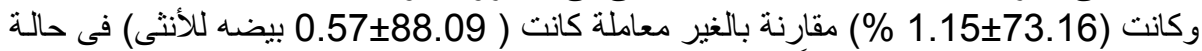

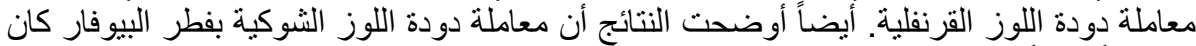

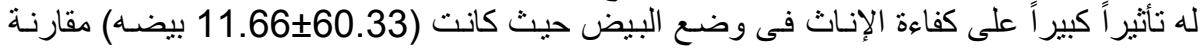

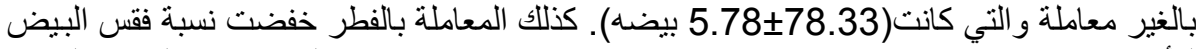

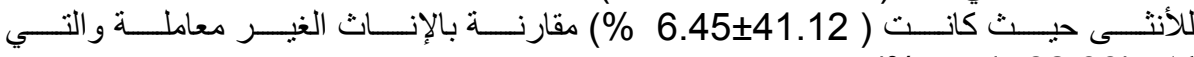

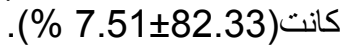

كلية الزراعة - جامعة المنصورة مركز البحوث الزراعية

\author{
قام بتحكيم البحث

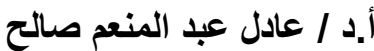 \\ أ.د / سامى ابو الفتوح عبد الواحد
}

